直径 $5 \mathrm{~cm}$ 以下の肝細胞癌 11 切除例の臨床病理学的検討

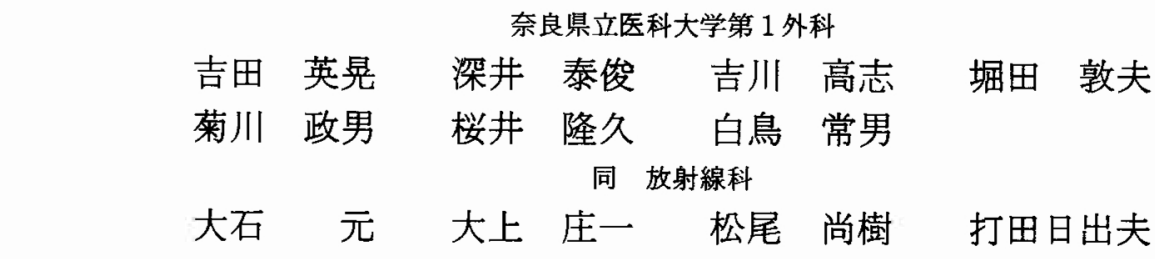

\title{
CLINICOPATHOLOGICAL STUDIES OF 11 HEPATOCELLULAR CARCINOMAS SMALLER THAN 5CM IN DIAMETER WITH HEPATIC RESECTION
}

\author{
Hideaki YOSHIDA, Yasutoshi FUKAI, Takashi YOSHIKAWA, \\ Atuo HOTTA, Masao KIKUKAWA, Takahisa SAKURAI \\ and Tuneo SHIRATORI
}

First department of Surgery, Nara Medical University

Hajime OHISHI, Shoichi OHUE, Naoki MATSUO and Hideo UCHIDA

Department of Radiology, Nara Medical University

\begin{abstract}
腫瘍径が $5 \mathrm{~cm}$ 以下の肝癌 11 切除例の臨床的検討結果を報告するとともに, これら症例の腫瘍の浸潤 の状態, 腫瘍の組織型, 非腫瘍部の病变を教室でこれまでに経験した腫瘍径 $5 \mathrm{~cm}$ 以上の肝癌と腫瘍径 別に病理組織学的に対比検討した. 腫瘍径別の組織像は径 $3 \sim 5 \mathrm{~cm}, 3 \mathrm{~cm}$ 以下では全例に被膜形成があ るも門脈内腫瘍塞栓は腫湯径と関保なく $75 \sim 93 \%$ に認めた。被膜への浸潤の程度も腫場径之関係なく $50 \%$ 以上の症例に認めた。腫瘍部の組織型は $3 \mathrm{~cm}$ 以下では高分化型のものが多く, 肝硬変の合併は $5 \mathrm{~cm}$ 以上の $60 \%$ に比べて, $5 \mathrm{~cm}$ 以下では $88 \sim 100 \%$ と高率にみられた。腫瘍径が $3 \mathrm{~cm}$ 以下の肝癌でも早期癌 といえる所見ではなく，さらに小型の肝癌を発見し検討する必要がある。
\end{abstract}

索引用語：肝細胞癌, 肝切除, 門脈内腫瘍塞栓, 娘結節, 肝硬変症

I.はじめに

近年, 血清生化学的検査, 種々の画像診断法の進歩 にともない, 臨床期以前の小さな肝癌の診断率が向上 してきている。しかし小さな肝癌例には高率に肝腺維 症や肝硬変を合併するため, 手術後にしばしば重篤な 合併症を抗こす。さらに高率に肝内脈管系に腫漡塞栓 を認め, 術後早期の再発例がみられて扣り ${ }^{3)}$, 腫瘍径の 小さな肝癌でるその治療に多くの問題があり, 長期生 存例を得るのに困難を要するのが現状である.

われわれは過去 6 年間に教室ならびに関連病院で最 大径 $5 \mathrm{~cm}$ 以下の肝細胞癌 11 切除例を経験したのでそ の臨床的検討結果を報告する，さらにこれらの症例の

$<1984$ 年6月13日受理 $>$ 別刷請求先：吉田 英晃 T634 檟原市四条町 840 奈良県立医科大学第 1 外科
腫瘍の浸潤状態, 腫瘍の組織型, 非腫瘍部の病変を教 室でこれまでに経験した腫場径 $5 \mathrm{~cm}$ 以上の肝細胞癌 と腫瘍径別に病理組織学的に対比検討したので報告す る.

\section{II. 対象および方法}

奈良医大第1外科および関連病院に扣いて肝切除し た最大径 $5 \mathrm{~cm}$ 以下の肝細胞癌 11 例を対象とした（表 1). 対象症例は従来の「董瘍 1 個最大径 $5 \mathrm{~cm}$ 以下また は主腫瘤 $4 \mathrm{~cm}$ 以内で娘病巣数個以内」の定義にかなっ たもので「細小肝癌」と略称した。腫瘍は症例 8 に 2 コ認めたが，その他の症例はすべてが単発であり，初 回手術例であった。各症例について各種検査成績, 病 理組織的所見, 治療方法㧍よび予後について検討した. さらにこれら11例と救室でこれまでに経験した腫煬径 か゚ $5 \mathrm{~cm}$ 以上の肝細胞癌の中病理組織が明らかにな 45 
表 1 直径 $5 \mathrm{~cm}$ 以下の肝細胞癌 11 切除例の診断法, 手術術式と予後

\begin{tabular}{|c|c|c|c|c|c|c|c|c|c|}
\hline \multirow[b]{2}{*}{ 症例 } & \multirow[b]{2}{*}{ 年令 } & \multirow[b]{2}{*}{ 性別 } & \multirow{2}{*}{ 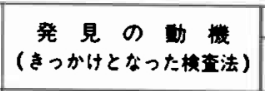 } & \multicolumn{2}{|c|}{ 術前 } & \multirow[b]{2}{*}{ 谁定粀断法 } & \multirow[b]{2}{*}{ 堙庶径 $(\mathrm{cm})$} & \multirow[b]{2}{*}{ 術 } & \multirow[b]{2}{*}{ 子 後 } \\
\hline & & & & $\begin{array}{c}\text { AFP值 } \\
(\mathrm{ng} / \mathrm{ml})\end{array}$ & HBs 抗原 & & & & \\
\hline 1 & 61 & $\delta$ & 肝雷 破 瑟 & せす & + & 手術所見 & $\begin{array}{c}\text { Ts } \\
3.5 \times 3 \times 3\end{array}$ & $\operatorname{HrO} O(A)$ & $\begin{array}{l}\text { 2年 } 2 \text { ヶ月 } \\
\text { 再手術後死 }\end{array}$ \\
\hline 2 & 68 & $q$ & $\begin{array}{l}\text { 恨性肝疾患にて精查中 } \\
\text { (肝シンチ) }\end{array}$ & 510 & - & 血管造影 & $\begin{array}{c}T_{1} \\
5 \times 5 \times 5\end{array}$ & $\operatorname{Hr} 1(L)$ & $\begin{array}{c}1 \text { 年10ヶ月 } \\
\text { 再発死 }\end{array}$ \\
\hline 3 & 60 & $\delta$ & 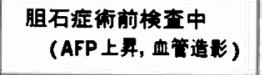 & 1400 & - & 血管造影 C.T. & $\begin{array}{c}T_{1} \\
3 \times 3 \times 3.2\end{array}$ & $\operatorname{Hr} 1(L)$ & $\begin{array}{l}4 \text { 年 } \\
\text { 再発死 }\end{array}$ \\
\hline 4 & 48 & $\delta$ & $\begin{array}{l}\text { 惯性肝疾患にて精査中 } \\
\text { (C.T.) }\end{array}$ & 8 & - & 血管造夥 & $\begin{array}{c}\text { Ts } \\
2.5 \times 2.5 \times 1.5\end{array}$ & $\operatorname{HrO}(A)$ & $\begin{array}{c}2 \text { 年 } 8 \text { 月 } \\
\text { 再発死 }\end{array}$ \\
\hline 5 & 64 & $\delta$ & 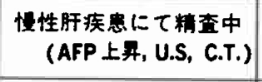 & 5.900 & - & 血管造到 & $\begin{array}{c}T s \\
4.3 \times 3.3 \times 4.0\end{array}$ & $\mathrm{HrO} O(A)$ & $\begin{array}{l}\text { 8ヶ月 } \\
\text { 再発死 }\end{array}$ \\
\hline 6 & 56 & $\delta$ & $\begin{array}{l}\text { 愯性肝疾患にて精查中 } \\
\text { (U.S, C.T) }\end{array}$ & 680 & - & 血管造影 & $\begin{array}{c}T_{1} \\
4 \times 4 \times 4\end{array}$ & $\operatorname{Hr} 2(P, A)$ & 術 死 \\
\hline 7 & 49 & $\delta$ & $\begin{array}{l}\text { 慢性肝疾患にて偨榅中 } \\
\text { (U.S, C.T) }\end{array}$ & 8.0 & - & 血管造颗 & $\begin{array}{c}\mathrm{Ts} \\
1.5 \times 1.5 \times 1.2\end{array}$ & $\operatorname{TAE}$ 後 $\operatorname{Hr} S(P)$ & $\begin{array}{c}\text { 2年6ヶ月 } \\
\text { 生存 }\end{array}$ \\
\hline 8 & 58 & $\delta$ & $\begin{array}{l}\text { 慢性肝疾患にて精査中 } \\
\text { (C.T.) }\end{array}$ & 248 & + & 血管造影 & $\begin{array}{c}\mathrm{Ts} \\
2 \times 1.5 \times 3.5 \\
2.8 \times 2.5 \times 0.7 \\
\end{array}$ & $\operatorname{HrO}(A)$ & $\begin{array}{c}1 \text { 年7ヶ月 } \\
\text { 生 存 }\end{array}$ \\
\hline 9 & 68 & $q$ & 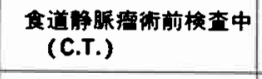 & 3.0 & - & c.T. & $\begin{array}{c}T_{1} \\
2 \times 2 \times 2.8\end{array}$ & 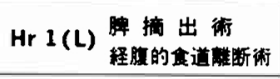 & $\begin{array}{l}1 \text { 年 } 5 \text { ヶ月 } \\
\text { 生 存 }\end{array}$ \\
\hline 10 & 65 & $\delta$ & $\begin{array}{c}\text { 惿性肝疾患にて精查中 } \\
\text { (U.S, C.T) }\end{array}$ & 2.6 & - & 血管造影 & $\begin{array}{c}T_{2} \\
5 \times 5 \times 5\end{array}$ & $\operatorname{TAE}$ 後 $\operatorname{Hr} 2(P, A)$ & 術死 \\
\hline 11 & 63 & $q$ & $\begin{array}{c}\text { 憬性肝疾患にて精查中 } \\
\text { (U.S, C.T) }\end{array}$ & 7.0 & - & 血管造影 & $\begin{array}{c}T_{\mathrm{S}} \\
3.3 \times 2.1 \times 2.3\end{array}$ & TAE後 HrS（尼状菜） & $\begin{array}{l}2 \text { ヶ月 } \\
\text { 生存 }\end{array}$ \\
\hline
\end{tabular}

例をもとに，腫痬径を $5 \mathrm{~cm}$ 以上，3 $5 \mathrm{~cm}, 3 \mathrm{~cm}$ 以下に 分けて, 腫媓の浸潤の状態，腫場の組織型そして非腫 痬部の組織像について比較検討した。

\section{III. 成 綨}

1. 直径 $5 \mathrm{~cm}$ 以下, 11 切除例の検討結果

1）性別と年㱓（表 1)

男性は 8 例，女性は 3 例で平均年齢60歳であった。

2）発見の動機と確定診断法（表 1)

3）術前 AFP 値および HBs 抗原（表 1)

術前の AFP 值は $400 \mathrm{ng} / \mathrm{ml}$ 以下が 6 例, その中 10 $\mathrm{ng} / \mathrm{ml}$ 以下が 5 例, $400 \sim 1,000 \mathrm{ng} / \mathrm{ml}$ が 2 例, 1,000 $\mathrm{ng} / \mathrm{ml}$ 以上が 2 例であった。肝癌破裂例は測定されて いない.

HBs 抗原は 2 例が陽性を示した。

4）手術方法之腫場の肉眼所見（表 1)

手術術式は右 2 区域切除が 2 例，外側区域切除が 3 例, 亜区域切除が 2 例(その中 1 例は尾状葉切除)，肝 部分切除が 4 例であった。

肝癌発見の動機は慢性肝疾患で経過観察中にAFP 値の上昇がきっかけとなった症例が 4 例, AFP 值は低
值であったが慢性肝疾患の経過観察中に超音波検査あ るいはCTを行い, 畽瘍の検出のきっかけとなった症 例が 6 例, 肝癌破裂で発見されたものが 1 例であった。

腫場の確定診断は 8 例が血管造影により，1 例は CT のみ, 1 例は血管造影と CT 所見, 残りの 1 例は手 術所見によりなされた。

症例7, 10,11は術前に trans catheter arterial embolization（以下 TAE と略す）を施行している。

腫湟の肉眼分類はすべてが結節型である。

腫瘍径は最大が $5 \times 5 \times 5 \mathrm{~cm}$, 最小が $1.5 \times 1.5 \times 1.2$ cmであった。

5）切除標本の病理学的所見 (表 2)

肝の切除標本は約 4 5mm 幅にスライスして検索し た。腫煬部の Edmondson 分類 (以下 Ed 分類と略す) は grade I $か ゙ 1$ 例, grade II $か ゙$ 例, grade III が 2 例, grade IV が 2 例そして TAE 後のため判定不能が 1 例であった。被膜形成, 被膜への漫潤, 門脈内腫瑒塞 栓の存在について検索したところ, 全例に被膜形成が みられ，被膜への浸潤は 9 例，さらに門脈内畽湯塞栓 は 8 例にみられた。非癌部の組織は 8 例に乙型肝硬変, 
表 2 直径 $5 \mathrm{~cm}$ 以下の肝細胞癌 11 切除例の病理組織 学的所見

\begin{tabular}{|c|c|c|c|c|c|}
\hline 症例 & $\begin{array}{c}\text { Edmondson } \\
\text { 分類 }\end{array}$ & 被膜形成 & 被膜漫湖 & 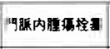 & 阱存肝病要 \\
\hline 1 & I & + & + & + & $z$ \\
\hline 2 & v & + & + & + & $z$ \\
\hline 3 & II & + & + & + & $z$ \\
\hline 4 & II & + & + & + & 2 \\
\hline 5 & II & + & + & + & 2 \\
\hline 6 & $\mathrm{~N}$ & + & + & + & $z$ \\
\hline 7 & II & + & - & + & $z$ \\
\hline \multirow{2}{*}{8} & IIII & + & + & - & \multirow{2}{*}{$z$} \\
\hline & III & + & + & - & \\
\hline 9 & 11 & + & - & - & $z$ \\
\hline 10 & II & + & + & + & 性活铺性肝炎 \\
\hline 11 & 不明 & + & - & - & $z$ \\
\hline
\end{tabular}

表 3 腫瘍径別病理組織学的所見

\begin{tabular}{|c|c|c|c|c|c|c|c|c|c|c|}
\hline \multirow{2}{*}{ 䭪徍 } & \multirow{2}{*}{ 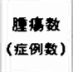 } & \multicolumn{5}{|c|}{ Edmondson 分類 } & \multirow{2}{*}{ 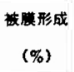 } & \multirow{2}{*}{ 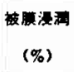 } & \multirow{2}{*}{ 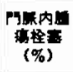 } & \multirow{2}{*}{$\begin{array}{c}\text { 计喽变合併 } \\
(\%)\end{array}$} \\
\hline & & I & II & ili & N & 不明 & & & & \\
\hline$>5 \mathrm{~cm}$ & $\begin{array}{c}45 \\
(45)\end{array}$ & 0 & 15 & 21 & 9 & 0 & $\begin{array}{c}8 \\
(18)\end{array}$ & $\begin{array}{c}5 \\
(62.5)\end{array}$ & $\begin{array}{c}42 \\
(93)\end{array}$ & $\begin{array}{c}27 \\
(60)\end{array}$ \\
\hline $3 \sim 5 \mathrm{~cm}$ & $\begin{array}{c}8 \\
(7)\end{array}$ & 1 & 2 & 2 & 2 & 1 & $\begin{array}{c}8 \\
(100)\end{array}$ & $\begin{array}{c}7 \\
(88)\end{array}$ & $\begin{array}{c}6 \\
(75)\end{array}$ & $\begin{array}{c}7 \\
(88)\end{array}$ \\
\hline$<3 \mathrm{~cm}$ & $\begin{array}{c}4 \\
\text { (4) }\end{array}$ & 0 & 4 & 0 & 0 & 0 & $\begin{array}{c}4 \\
(100)\end{array}$ & $\begin{array}{c}2 \\
(50)\end{array}$ & $\begin{array}{c}3 \\
(75)\end{array}$ & $\begin{array}{c}4 \\
(100)\end{array}$ \\
\hline
\end{tabular}

2 例に乙'肝硬変, 1 例に慢性活動性訮资を合併してい た.

\section{6）手術成績と遠隔成績（表 1 ）}

手術死亡は症例 6 と症例10の 2 例であった. 1 年以 上生存は 7 例, 2 年以上生存は 4 例, 最長生存は症例 3 の 4 年の再発死例である. 1 年以内の再発死は症例 5 の 1 例であった。

2. 肝細胞癌の腫瘍径別病理組織学的所見（表 3)

教室で経験した肝細胞癌例の中，病理組織が明らか な56例をもとに，腫瘍径を $5 \mathrm{~cm}$ 以上，3〜 $5 \mathrm{~cm}, 3 \mathrm{~cm}$ 以 下に分けたところ，腫湯数は $5 \mathrm{~cm}$ 以上は 45 個， $3 \sim 5 \mathrm{~cm}$ は 8 個， $3 \mathrm{~cm}$ 以下は 4 個であった（症例 8 に腫湟が 2 個あるため重複している)。腫場部の $\mathrm{Ed}$ 分類は $5 \mathrm{~cm}$ 以 上では grade II〜III に分布し，3－5cm ではとくに傾 向はみられず，3cm 以下では grade II に分布する傾向 にあった。被膜の形成は $5 \mathrm{~cm}$ 以下の全例に認めたが, $5 \mathrm{~cm}$ 以上では $18 \%$ に認めるのみであった，被膜への浸 潤の頻度は腫瘍径と関係なく50\%以上にみられた。門 脈内腫湯塞栓は腫湟径と関係なく, その頻度は 75〜93\%と高率にみられた。肝硬変の合併率は $5 \mathrm{~cm}$ 以 上では66\%であるのに対し，5cm 以下では $88 \sim 100 \%$
困 1 症例 5 の術前肝血管造影像, 右葉前下区域に $4 \times$ $4 \mathrm{~cm}$ の範囲に腫㻛血管を認める.

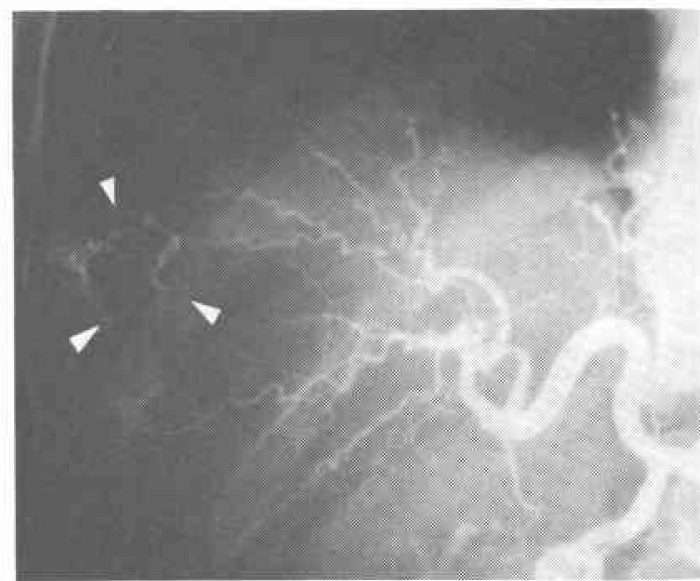

と高率に認めた。

以下，術前より主腫瘍以外の肝区域に微小娘結節が 存在し，術後早期に再発死したと考えられた症例 5 , および腫瘍径が $1.5 \times 1.5 \times 1.2 \mathrm{~cm}$ であったが門脈内 に腫瘍栓を認めた症例 7 を供覧する。

症例5.64歳, 男性.

慢性肝疾患で経過観察中 AFP 值が $5,900 \mathrm{ng} / \mathrm{ml}$ に 上昇し, 精査を目的に肝シンチ, 超音波検査, CTを施 行したところ肝右葉に $4 \times 4 \mathrm{~cm}$ の腫瘍を発見した。血 管造影で肝右葉前下区域に hypervascularな腫瘍を 認め（図 1) 肝細胞癌と診断した。Couinaud SV の部 分切除を行った。摘出肝重量は220gm, 腫瘍は黄白色を 呈し，被膜を有する結節型の腫瘍で，大きさは $4.3 \times$ $3.3 \times 4.0 \mathrm{~cm}$ であった。 その近傍にも $0.3 \mathrm{~cm}$ の娘結節 を認めた(図 2$)$ ，病理組織にて，主腫瘍と娘結節はい ずれも Ed 分類II型であった.さらに，その近傍の門脈 内にも腫瘍塞栓を認めた。術後に患者は一過性の腹水 貯留を認めたが重篤な合併症はなかった.AFP 值は術 後10日目には正常化したが，5週目頃より徐々に上昇 傾向を示し，8週目に行った血管造影では肝切除断端 に再発の所見を認めなかったが，右門脈本幹部に腫焬 血管を認めた（図 3 ). TAEを行い一時 AFP 値の下降 をみたが，腫湟の増大により術後34週目に死亡した。

症例 7.49歳, 男性.

20歳時に肝资の既往があり，内科を受診して，肝硬 変を指摘され，超音波と CT 検查で肝細胞癌が疑われ た. 入院時に精查の目的で施行したCTで，肝右葉後 区域に径 $2.3 \mathrm{~cm} の$ 低昅収域を, 肝動脈造影で右肝動脈 
図 2 症例 5 の肝切除標本, 主腫瘍の近傍に0.3cm 大 の娘結節（矢印）を認める。

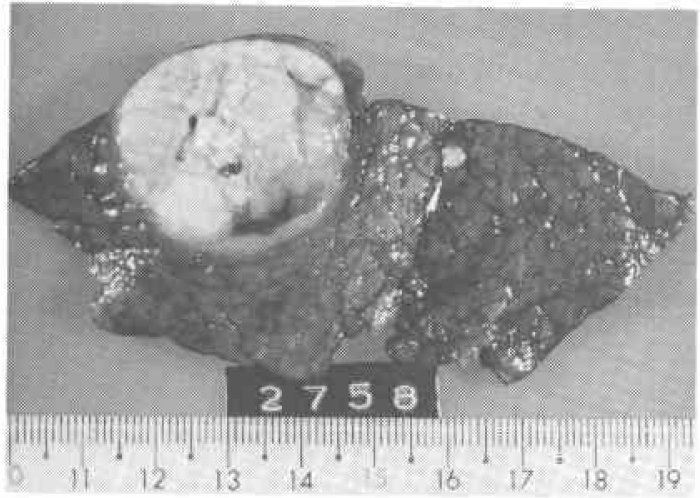

図 3 症例 5 の肝切除後 8 週目の肝動脈造影像肝門部 （矢印）に腫湯血管を認める。

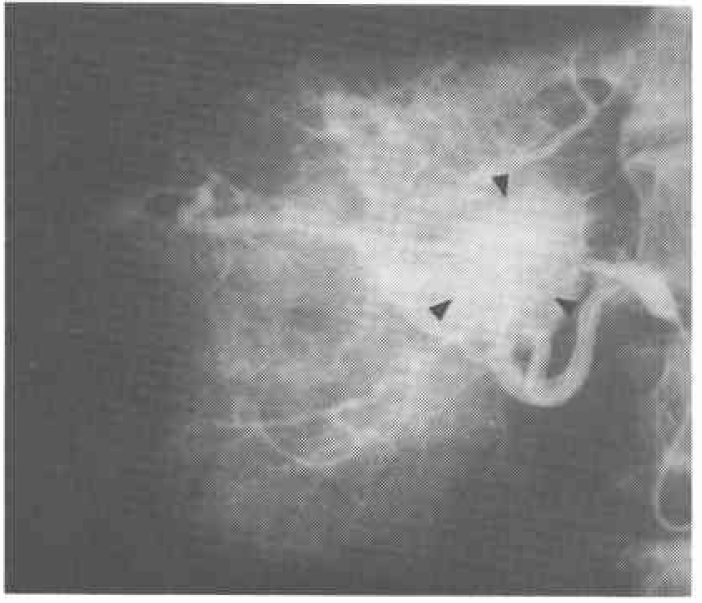

D後下枝領域に腫瘍血管と腫瘍濃染像を認めた. 同時期 にTAEを施行し, TAE 後 1 力月目にCouinaud SVI 切除を行った。摘出した腫瘍は $1.5 \times 1.5 \times 1.2 \mathrm{~cm}$ で厚 さ1mm の被膜を有する結節型の腫瘍で隣接して娘結 節を認めた。組織学的所見にて腫瘍は完全に壊死に陥 り，隣接してみられた数個の微小娘結節にも一部硝子 化をとすなら変性壊死傾向を認めた。娘結節の組織像 から主畽瘍は Ed 分類 II 型の肝細胞癌が考之られた (図 4). 主腫場近傍の門脈内にはすでに腫瘍栓塞がみ られて拈り，TAEによる変性所見はなかった（図 5). とくに合併症もなく退院し, 術後 2 年 6 力月現在元気 に社会復㷌している（本症例の詳細はすでに報告し だ).
図 4 症例 7 の $\mathrm{TAE}$ 後 1 力月の肝腫瘍部 (A) と娘結 節部（B）の病理組織像，A部において腫瘍の完全 壊死，B部において一部硝子化をとるなら変性壊死 傾向を認める。

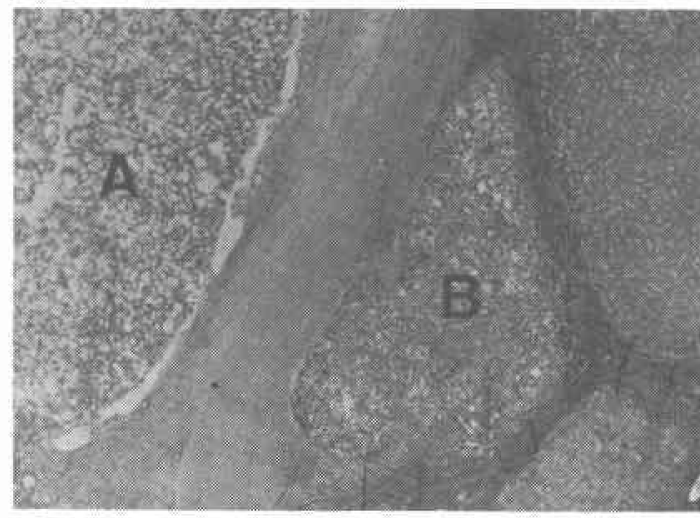

因 5 症例 7 の病理組織像, 主腫瘍近傍の門脈内には すでに腫瘍塞栓を綛める。

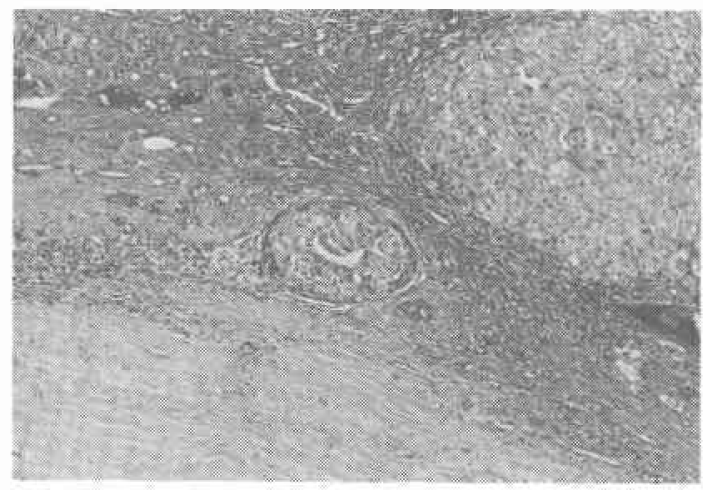

\section{IV. 考察}

\section{1. 細小肝癌発見の動機}

肝癌発見のきっかけとしてAFPの高値による場合 があるが，細小肝癌の AFP 值は低産生性である場合 が多く, 安藤ら5の集計によれば細小肝癌64例中, AFP 值が $1,000 \mathrm{ng} / \mathrm{ml}$ をこえたるのは21例 (32.8\%)にすぎ ず, $400 \mathrm{ng} / \mathrm{ml}$ 末満のものは30例 $(46.2 \%)$ もった. 報告の症例です AFP が測定出来た 10 例中 $1,000 \mathrm{ng} / \mathrm{ml}$ 以上が 2 例, $400 \mathrm{ng} / \mathrm{ml}$ 以下が 6 例あり，その中 5 例が $10 \mathrm{ng} / \mathrm{ml}$ 以下を示した. AFP 値のみによるひろいあげ 診断は困難である。しかし，AFP 低産生群を含めて， 細小肝癌のほとんどの症例が慢性肝疾患で治療中に肝 シンチ，超音波あるいはCTなどの画像診断を受け， 診断の手がかりとなっている. 
近年画像診断法による肝癌の診断能は著しく向上し ており，超音波診断法により発見可能な肝癌の最小径 む1.5 3.0 cm と向上してきており，品川らら类は肝シン チ, CT, 超音波, 肝血管造影による小肝腫瘍の診断能 は3 $5 \mathrm{~cm}$ 例では超音波は他の検查と差はなかった が，3cm 以下では $91 \%$ と最すすぐれた検出能を示した と報告している。

CT 検査による診断は Itai らの報告》では多発性肝 癌の場合直径 $2.5 \mathrm{~cm}$ までが可能であったと報告して 扣り，大上ら ${ }^{8)}$ は直径 $2.0 \mathrm{~cm}$ がCTによるひろいあげ 診断の限界と報告している. 症例 7 も腫瘍径が $1.5 \times$ $1.5 \times 1.2 \mathrm{~cm}$ であったが，慢性肝疾患にて経過観察中 CTにて肝癌を発見することが可能であった。

畽瘍径が $2 \mathrm{~cm}$ までの小さな肝癌のひろいあげ診断 には, AFP の変動に注目しつつ, 無侵襲な超音波検査 およびCT 検査を定期的に行うことがスクリーニング

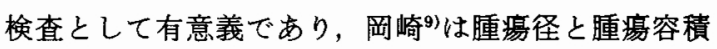
の doubling time からの検討で肝癌を $2 \mathrm{~cm}$ 以下で確実 に診断するためには 3 力月に 1 回の画像検查が必要で あると報告している。

\section{2. 腫瘍径別の病理学的所見}

表 3 のごとく, 腫瘍径 $5 \mathrm{~cm}$ 以下の全例に被膜形成を 認めたが, $3 \mathrm{~cm}$ 以下の 4 例中 2 例に被膜浸潤を認めて おり門脈内腫瘍塞栓も $5 \mathrm{~cm}$ 以上とほぼ同様に高率化 認めた。ささらに供覧した尰瘍径 $1.5 \times 1.5 \times 1.2 \mathrm{~cm}$ 例に おいてもすでに娘結節が存在し, 門脈内に腫場塞栓が 認められており, 京井 ${ }^{10}$ は $1.5 \times 1.4 \times 0.7 \mathrm{~cm}$ の肝癌に 数個の娘結節の存在之腫瘍の被膜外への浸潤を報告し ている. 広岡ら ${ }^{11)} 3 \mathrm{~cm}$ 以下の肝癌 16 例の病理学的検 討でも $85.7 \%$ に被膜浸潤，75\%に血管漫潤を認めたと 報告している。これらの事実から $3 \mathrm{~cm}$ 以下の肝癌でも 高率に進行癌の様相を呈することがうかがえる。最大 径2 3cm の肝癌が $\mathrm{CT}$, 超音波検查によるひろいあげ 診断の限界とすると検出される肝癌に高率に進行癌が 含まれることになり，さらに精度の高い診断方法が望 まれる。

\section{3. 治療方法}

腫瘍径 $3 \mathrm{~cm}$ 以下の症例にも高率に門脈内腫瘍塞栓 がみられることから, 広範肝切除を行うことが望まし いが, $5 \mathrm{~cm}$ 以下の肝癌では $5 \mathrm{~cm}$ 以上の症例に比べ高率 に肝硬変を合併するため, ほとんどの症例は 1 区域以 内の切除に留るるのが現状である。しかし，供覧した 症例 5 のごとく, 術前にすでに主腫煌と別の肝区域に 画像診断法では描出できない，娘結節が存在して
いたと考えられる症例があり，現状でより根治的な治 療を行うには, 術前により精度の高い画像診断法を用 いて主腫湯と微小娘結節を検出し，切除するとともに 術後に制癌剂を投与することになる。

肝癌の集学的治療の一環としてわれわれは術前に TAE を施行しているが, TAEの塞栓物質として抗癌 剂混入油性造影剤(Lipiodol)を肝動脈内に注入後の経 時的 CT (以下 LPCT と略す) により観察したところ, 微小娘結節の検出に infusion hepatic angiography 上 りすぐれた成績が得られ，血管造影で描出されなかっ た径2 3mm の腫煬を検出することができた ${ }^{12)}$. 主腫 湯と微小娘結節の検出に LPCT は精度の高い画像診 断法と考光現在症例をかさねて検討中である.

\section{結語}

(1) 尰寡径が $5 \mathrm{~cm}$ 以下の肝癌の AFP 值は低値を示 すものが多かったが，ほとんどの症例が慢性肝疾患を 合併するため, AFP 値と CT または超音波検査を併用 することにより高い診断能が得られた。

(2) 厘瘍径が $3 \mathrm{~cm}$ 以下, $3 \sim 5 \mathrm{~cm}$ 肝癌は全例に被膜の 形成があるも $5 \mathrm{~cm}$ 以上の肝癌とほぼ同様に高率に門 脈内に畽場塞栓が存在し，50\%以上の症例に被膜への 浸潤がみられ，腫場径が $1.5 \times 1.5 \times 1.2 \mathrm{~cm}$ の症例にも 娘結節や門脈内隀煬塞栓がみられたことから， $3 \mathrm{~cm}$ 以 下の肝癌でも早期癌といえる所見ではなかった。

(3) 腫瘍径が $3 \mathrm{~cm}$ 以下の肝癌の組織像は高分化型の ものが多かった。

(4) 腫場径が $5 \mathrm{~cm}$ 以下の肝癌には高率に肝硬変が認 められ，5cm 以上に比べてその合併率が高かった。

\section{文献}

1）石川浩一：原発性肝癌症例に関する追跡調查一第 3 報一。肝臟 $17: 460-465,1976$

2）中沼安二, 太田五六, 松原藤継：細小肝癌14例の細 胞学的, 構造学的変化扣よび HBs 抗原の出現頻度 一大型肝癌との比較一, 肝葴 $21: 1655-1662$, 1980

3）山崎 晋, 長谷川博, 幕内雅敏：細小肝癌の臨床病 理学的分析々それにもとづく新しい概念の切除法 -27 切除例の検討一. 肝臓 $22: 1714-1723,1981$

4）吉川高志, 吉田英晃, 深井泰俊注か：肝動脈塞栓術 が微小娘結節に有効であった細小肝細胞癌の 1 切 除例。日消外会誌 $16: 718-720,1983$

5）安藤啓次郎, 冲田 極, 渡辺精四郎ほか：肝細胞癌 早期唁断のための screening 法の検討一肝細胞癌 合併 high risk group設定の試み。肝葴 22 ： $1162-1170,1981$

6）品川 孝, 大藤正雄, 木村邦夫㴽か：小肝細胞癌の 
湢床。日消病会誌 79：2277-2284，1982

7) Itai $Y$, Nishikawa J, Tasaka A : A computed tomography in the evaluation of hepatocellular carcinoma. Radiology $131: 165-170,1979$

8）大上庄一, 大石 元, 黒畸喜久ほか：細小䀒壐の CT Кよる検討. 画像䛦断 $12: 785-793 ， 1982$

9）岡崎伸生, 吉野正堚, 吉田孝宜はか：肝細胞癌の発 育速度と早期診断。肝壐 $22: 1742 ， 1981$
10）京井優典, 川上 究, 柳瀬晴也はか：胲小癌の 1 切除侧. 肝硔 20:966-971，1979

11）広岡 昇, 岩崎 夏: 小肝癌の腫瘍構造とその進

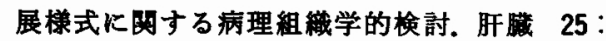
384-392, 1984

12）大石 元，打田日出夫, 大上庄一ほか：肝細胞癌の 娘結節診断に対する Lipiodol 動注後 CT の評価. 肝臟 $25: 266,1984$ 